medRxiv preprint doi: https://doi.org/10.1101/2021.05.10.21256804; this version posted May 10, 2021. The copyright holder for this preprint (which was not certified by peer review) is the author/funder, who has granted medRxiv a license to display the preprint in perpetuity.

It is made available under a CC-BY 4.0 International license.

\title{
Transdiagnostic phenotyping of psychopathology in a help-seeking population (PhenoNetz) - a study protocol for an experience sampling study
}

\author{
Marlene Rosen ${ }^{1 \# *}$, Linda T. Betz ${ }^{1 *}$, Christian Montag ${ }^{2}$, Christopher Kannen ${ }^{2}$, Joseph \\ Kambeitz ${ }^{1}$
}
${ }^{1}$ Department of Psychiatry and Psychotherapy, Faculty of Medicine and University Hospital of Cologne, Cologne, Germany
${ }^{2}$ Institute of Psychology and Education, Ulm University, Ulm, Germany

${ }^{\#}$ Corresponding Author
E-mail: marlene.rosen@uk-koeln.de

* These authors contributed equally to this work.

This article is a preprint and has not been peer-reviewed. 
medRxiv preprint doi: https://doi.org/10.1101/2021.05.10.21256804; this version posted May 10, 2021. The copyright holder for this preprint (which was not certified by peer review) is the author/funder, who has granted medRxiv a license to display the preprint in perpetuity.

It is made available under a CC-BY 4.0 International license.

\section{Metadata}

\section{Funding}

The study is funded by the Köln Fortune program, Faculty of Medicine, University of

Cologne (grant agreement $\left.\mathrm{n}^{\circ} 304 / 2020\right)$.

\section{Competing interests}

The authors declare that no competing interests exist.

\section{Data availability}

All relevant data from this study will be made available upon study completion. 
medRxiv preprint doi: https://doi.org/10.1101/2021.05.10.21256804; this version posted May 10, 2021. The copyright holder for this preprint (which was not certified by peer review) is the author/funder, who has granted medRxiv a license to display the preprint in perpetuity.

It is made available under a CC-BY 4.0 International license .

\begin{abstract}
Background: Prevention in psychiatry provides a promising way to address the burden by mental illness. However, established approaches focus on specific diagnoses and do not address the heterogeneity and manifold potential outcomes of help-seeking populations that present at early recognition services. Thus, novel preventive approaches have been suggested, focusing on a broad transdiagnostic risk syndrome associated with different mental disorders. Conceptualizing such a pluripotent risk syndrome from a network perspective of interacting symptoms allows transdiagnostic investigations beyond binary disease categories.
\end{abstract} Furthermore, modern technologies such as smartphones facilitate the application of Experience Sampling Methods (ESM). A combination of ESM with network analyses provides valid insights beyond established assessment instruments.

Methods: We will examine $\mathrm{n}=75$ individuals (age 18-40 years) of the help-seeking population of the Cologne early recognition centre (FETZ). For a maximally naturalistic sample, only minimal exclusion criteria will be applied. We will collect data for 14 days utilizing a mobile application to assess ten transdiagnostic symptoms, i.e., depressive, anxiety and psychotic symptoms as well as distress level. These data will allow to build both personalized and group symptom network models. Additionally, we will explore associations between symptom networks and sociodemographic, risk and resilience factors, as well as psychosocial functioning.

Discussion: Our study will provide insights about feasibility and utility of ESM in a helpseeking population. Providing a first explorative phenotyping of the proposed broad transdiagnostic risk syndrome, this study will contribute to innovation of early recognition in psychiatry. Results will help to pave the way for prevention and targeted early intervention in a broader patient group and thus, enable greater intended effects in alleviating the burden of 
medRxiv preprint doi: https://doi.org/10.1101/2021.05.10.21256804; this version posted May 10, 2021. The copyright holder for this preprint (which was not certified by peer review) is the author/funder, who has granted medRxiv a license to display the preprint in perpetuity.

It is made available under a CC-BY 4.0 International license.

psychiatric disorders. In particular, individual insights provided by our study design are important in the context of precision medicine as well as for patients' own self-management. 
medRxiv preprint doi: https://doi.org/10.1101/2021.05.10.21256804; this version posted May 10, 2021. The copyright holder for this preprint (which was not certified by peer review) is the author/funder, who has granted medRxiv a license to display the preprint in perpetuity.

It is made available under a CC-BY 4.0 International license .

\section{Introduction}

Prevention and early intervention in psychiatry provide promising ways to address the immense burden of mental illness [1-3]. The currently established prevention approach implemented in early recognition services focuses on risk syndromes developed for predicting specific diagnoses (e.g. psychosis $[4,5])$. However, the majority of help-seeking patients who present at early recognition services are not covered by these specific risk syndromes, as they do not fulfill respective criteria which indicate increased risk qualifying for targeted intervention [4,6]. Help-seeking populations rather present with a mixture of various symptoms [7] such as depressive, anxious and psychotic symptoms. Depressive and anxiety symptoms have proven to be among the main reasons why individuals seek help [8], whereas psychotic symptoms are of interest as they are most burdensome for affected individuals as well as for the health care system, despite their rather low prevalence [9]. These symptoms are shared across different diagnoses [10-12] and appear in help-seeking patients with sub-threshold, risk-syndromes and full-threshold disorders [13]. Furthermore, full-threshold disorders such as mild depression may also represent a risk status for other, more severe mental illnesses, such as severe recurring depression [14]. Taken together, helpseeking populations are much more heterogeneous than defined in specific risk syndromes. In turn, those patients who fulfill criteria of a specific risk syndrome may remain or remit in risk state, develop manifold potential outcomes [15] or show other unfavorable outcomes such as persisting deficits in psychosocial functioning [16]. To date, it is unclear why a high number of disease specific risk-syndromes are associated with other disorders (multifinality) and why various risk factors seem to pave the way to the same disorders (equifinality of divergent trajectories) [17-19].

Thus, there is a growing call for a new approach for prevention in psychiatry assuming a broad transdiagnostic risk syndrome. This broad transdiagnostic risk syndrome 
medRxiv preprint doi: https://doi.org/10.1101/2021.05.10.21256804; this version posted May 10, 2021. The copyright holder for this preprint (which was not certified by peer review) is the author/funder, who has granted medRxiv a license to display the preprint in perpetuity.

It is made available under a CC-BY 4.0 International license .

represents an early shared pathway to different psychiatric disorders [20], in keeping with accumulating evidence about transdiagnostic phenomena in psychiatry such as distress, which is discussed as a mediating and triggering factor in mental illness [21-25]. However, insights into the structure of psychopathology of this proposed transdiagnostic risk syndrome, i.e., interactions of symptoms of a heterogeneous help-seeking population, as well as associations with risk and resilience factors and psychosocial functioning, is lacking so far.

Conceptualizing the transdiagnostic risk syndrome from a network perspective allows investigations beyond binary disease categories. The network approach considers and, thus, enables to assess the complex dysfunctional process of a psychopathological state as a dynamic system of connected, interacting and maintaining symptoms [26,27]. Moreover, the impact of individual and environmental factors on these personalized dynamic systems can be assessed.

Particularly in combination with experience sampling methods (ESM), network analyses enable insights beyond those obtained by standard established assessment instruments. ESM allows for valid insights into psychopathology in daily life by assessing targeted phenomena repeatedly during the course of the day within a specific time period. Thereby, ESM guarantees high reliability, eliminating biases resulting from false memory or aggregation processes of experience over a longer time period [28]. Feasibility and acceptance of such high frequent assessments is facilitated by modern technologies such as smartphones (see [29] and [30]). The intensive time-series data resulting from ESM provide insights not only on group, but also on individual level, offering a promising gateway into understanding psychopathology as a set of person-specific dynamic processes [27,31]. These unique insights are crucial for precision medicine as they reveal processes and symptoms most relevant to each individual, which may serve as potential target points for personalized interventions [32]. In addition, learning about specific individual processes underlying their 
medRxiv preprint doi: https://doi.org/10.1101/2021.05.10.21256804; this version posted May 10, 2021. The copyright holder for this preprint (which was not certified by peer review) is the author/funder, who has granted medRxiv a license to display the preprint in perpetuity.

It is made available under a CC-BY 4.0 International license .

mental states can improve self-management of individuals, reinforcing a sense of participation in one's own care $[33,34]$. So far, utility and potential of ESM in psychiatry were exclusively tested in the context of specific psychiatric diseases and not yet systematically in a help-seeking population of a psychiatric early recognition center. The combination of ESM with network analyses allows for an informative transdiagnostic phenotyping in this population, and provides a still missing characterization of the proposed transdiagnostic risk syndrome. The results can form the basis for future preventive approaches targeting a broad pluripotent risk syndrome. This represents a promising way to address a larger proportion of the help-seeking population than current diagnosis-specific strategies.

\section{Methods}

Aim

This study aims at an explorative transdiagnostic phenotyping of a help-seeking population of an early recognition center for mental disorders using innovative, intensive longitudinal data collection via a smartphone app. A better understanding of relevant psychopathology in this burdened population is of great relevance, given the lack of adequate interventions [35]. Combining ESM with network analyses allows for unique insights into yet under-researched early transdiagnostic psychopathological processes, as well as their association with risk, resilience, and psychosocial functioning.

\section{Setting and participants}

100 participants will be recruited from the help-seeking population presenting at the early recognition center of mental disorders at the University Hospital of Cologne (FETZ) (fetz.uk-koeln.de), with an expected drop-out rate of $25 \%$, leading to a total of 75 participants in the final sample. The FETZ offers specialist diagnostics for the early recognition of mental 
medRxiv preprint doi: https://doi.org/10.1101/2021.05.10.21256804; this version posted May 10, 2021. The copyright holder for this preprint (which was not certified by peer review) is the author/funder, who has granted medRxiv a license to display the preprint in perpetuity.

It is made available under a CC-BY 4.0 International license .

disorders, with a focus on severe mental illness, in particular psychotic disorders, and is a first contact point for people aged 18 to 40 years that have noticed changes in their experience and behaviour. Most patients find out about the FETZ through internet research or are referred to by healthcare practitioners.

For a naturalistic characterization of the help-seeking population presenting at the FETZ using ESM, we will not impose specific inclusion criteria for participation in the PhenoNetz-study. Likewise, to ensure validity of the obtained data, only a minor part of helpseeking participants will be excluded based on the following criteria:

- acute suicidal thoughts

- $\mathrm{IQ} \leq 70$

- age $>40$ years

- known previous illness of the central nervous system, as well as untreated unstable somatic illnesses with known effects on the central nervous system (e.g. untreated hypothyreosis)

- insufficient knowledge of the German language

\section{Procedure and materials}

All patients presenting at the FETZ not fulfilling any of the listed exclusion criteria will be addressed either directly in the FETZ or via telephone or e-mail (given permission to contact was obtained by the clinical personnel at the FETZ) and informed about background, goal, design, risks and benefits, as well as data security aspects of the study. Additional open questions will be answered directly by one of the primary investigators (MR, LB). In case of willingness to participate, written informed consent will be provided by all participants prior to their participation in the study. Participants will be compensated with $40 €$ for their participation. Participants can withdraw from the study at any time without negative 
medRxiv preprint doi: https://doi.org/10.1101/2021.05.10.21256804; this version posted May 10, 2021. The copyright holder for this preprint (which was not certified by peer review) is the author/funder, who has granted medRxiv a license to display the preprint in perpetuity.

It is made available under a CC-BY 4.0 International license .

consequences. The study was approved by the Institutional Review Board of the University of Cologne, Faculty of Medicine (reference number 20-1092).

Figure 1 illustrates the study design. During baseline assessment, data on sociodemographics, medication, substance use, psychopathology including psychosocial functioning as well as risk- and resilience factors will be assessed through both observer- and self-ratings (table 2). All data will be collected via Research electronic data capture (RedCap [36]). In the baseline assessment, the mobile application used for ESM data collection in the study, the insightsapp [37], will be installed on the personal smartphones of the participants. As the insightsapp only runs on Android, participants with personal smartphones using other operating systems (e.g., iOS) will be equipped with a study smartphone. Participants will be encouraged to complete as many surveys as possible without compromising their personal safety (e.g., while driving). 
medRxiv preprint doi: https://doi.org/10.1101/2021.05.10.21256804; this version posted May 10, 2021. The copyright holder for this preprint (which was not certified by peer review) is the author/funder, who has granted medRxiv a license to display the preprint in perpetuity.

It is made available under a CC-BY 4.0 International license.

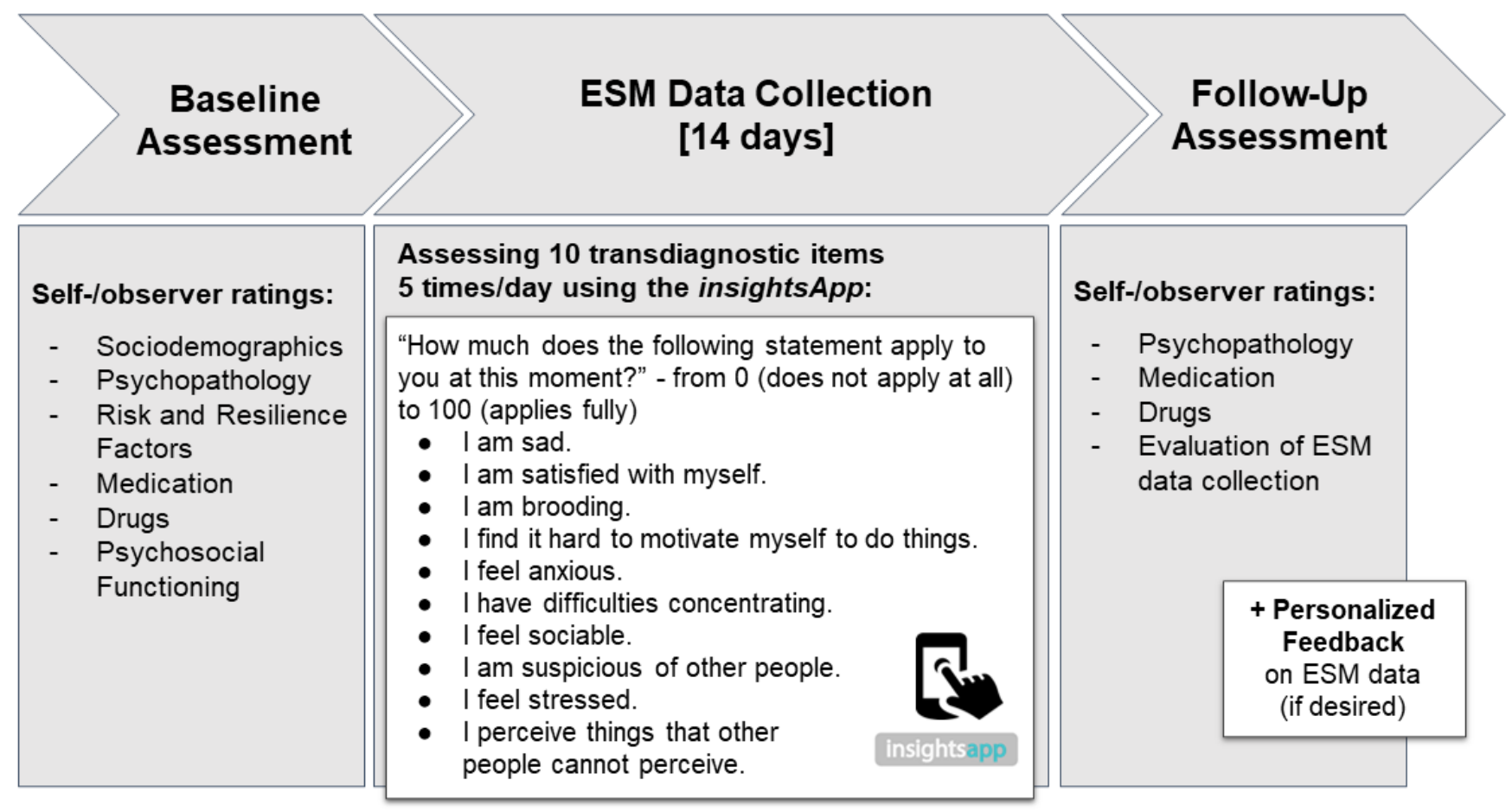

Figure 1. Study design of the PhenoNetz-study. Participants included will undergo baseline assessment with self- and observer ratings, followed by a 14-day-ESM data collection period. In the subsequent follow-up assessment, selected self- and observer ratings will be collected again. If desired, the participants will receive personalized feedback on their ESM data after the two weeks of ESM data collection, such that the feedback does not interfere with ESM data collection. 
medRxiv preprint doi: https://doi.org/10.1101/2021.05.10.21256804; this version posted May 10, 2021. The copyright holder for this preprint (which was not certified by peer review) is the author/funder, who has granted medRxiv a license to display the preprint in perpetuity.

It is made available under a CC-BY 4.0 International license.

Table 2. Constructs with scales assessed at the baseline and follow-up assessments (before and after the ESM period, respectively) of the PhenoNetz-study.

\begin{tabular}{|c|c|c|c|c|}
\hline Construct & Questionnaire & $\begin{array}{l}\text { Self- vs } \\
\text { observer- } \\
\text { rating }\end{array}$ & $\begin{array}{l}\text { Baseline } \\
\text { assessment }\end{array}$ & $\begin{array}{l}\text { Follow-up } \\
\text { assessment }\end{array}$ \\
\hline $\begin{array}{l}\text { sociodemogra } \\
\text { phics }\end{array}$ & - & $\begin{array}{l}\text { Observer } \\
\text { rating }\end{array}$ & $\mathrm{x}$ & - \\
\hline \multicolumn{5}{|l|}{$\begin{array}{l}\text { psychopatholo } \\
\text { gy }\end{array}$} \\
\hline $\begin{array}{l}\text { diagnostic } \\
\text { classification }\end{array}$ & $\begin{array}{l}\text { Structured Clinical Interview } \\
\text { for DSM-5 (SCID) [38] }\end{array}$ & $\begin{array}{l}\text { Observer } \\
\text { rating }\end{array}$ & $\mathrm{x}$ & - \\
\hline $\begin{array}{l}\text { current } \\
\text { substance use }\end{array}$ & $\begin{array}{l}\text { analogous to PRONIA study } \\
\text { [39] }\end{array}$ & $\begin{array}{l}\text { Observer } \\
\text { rating }\end{array}$ & $\mathrm{x}$ & $\mathrm{x}$ \\
\hline $\begin{array}{l}\text { current } \\
\text { medication }\end{array}$ & $\begin{array}{l}\text { analogous to PRONIA study } \\
\text { [39] }\end{array}$ & $\begin{array}{l}\text { Observer } \\
\text { rating }\end{array}$ & & $\mathrm{x}$ \\
\hline depression & $\begin{array}{l}\text { Beck Depression Inventory } \\
\text { (BDI-II) [40] }\end{array}$ & Self rating & $\mathrm{x}$ & $\mathrm{x}$ \\
\hline anxiety & $\begin{array}{l}\text { State and Trait Anxiety } \\
\text { Inventory (STAI) [41] }\end{array}$ & Self rating & $\mathrm{x}$ & $\mathrm{x}$ \\
\hline social phobia & $\begin{array}{l}\text { Social Phobia Inventory } \\
\text { (SPIN) [42] }\end{array}$ & Self rating & $\mathrm{x}$ & $\mathrm{x}$ \\
\hline $\begin{array}{l}\text { psychotic } \\
\text { symptoms }\end{array}$ & $\begin{array}{l}\text { Community Assessment of } \\
\text { Psychic Experience (CAPE) } \\
\text { [43] }\end{array}$ & Self rating & $\mathrm{x}$ & $\mathrm{x}$ \\
\hline quality of life & $\begin{array}{l}\text { WHO Quality of Life } \\
\text { Questionnaire (WHOQOL) } \\
\text { [44] }\end{array}$ & Self rating & $\mathrm{x}$ & $\mathrm{x}$ \\
\hline \multicolumn{5}{|l|}{$\begin{array}{l}\text { risk- and } \\
\text { resilience }\end{array}$} \\
\hline $\begin{array}{l}\text { childhood } \\
\text { trauma }\end{array}$ & $\begin{array}{l}\text { Childhood Trauma } \\
\text { Questionnaire (CTQ) [45] }\end{array}$ & Self rating & $\mathrm{x}$ & - \\
\hline bullying & Bullying Scale (BS) [46] & Self rating & $\mathrm{x}$ & - \\
\hline resilience & $\begin{array}{l}\text { Resilience Scale for Adults } \\
\text { (RSA) [47] }\end{array}$ & Self rating & $\mathrm{x}$ & - \\
\hline
\end{tabular}


medRxiv preprint doi: https://doi.org/10.1101/2021.05.10.21256804; this version posted May 10, 2021. The copyright holder for this preprint (which was not certified by peer review) is the author/funder, who has granted medRxiv a license to display the preprint in perpetuity.

It is made available under a CC-BY 4.0 International license .

\begin{tabular}{|c|c|c|c|c|}
\hline coping & $\begin{array}{l}\text { Coping Inventory for } \\
\text { Stressful Situations (CISS- } \\
\text { 24) [48] }\end{array}$ & Self rating & $x$ & - \\
\hline personality & $\begin{array}{l}\text { NEO - Five Factor } \\
\text { Inventory (NEO-FFI) [49] }\end{array}$ & Self rating & $x$ & - \\
\hline attachment & $\begin{array}{l}\text { Attachment Style } \\
\text { Questionnaire (ASQ) [50] }\end{array}$ & Self rating & $\mathrm{X}$ & - \\
\hline $\begin{array}{l}\text { expressed } \\
\text { emotion }\end{array}$ & $\begin{array}{l}\text { Level of Expressed Emotion } \\
\text { Scale (LEE) [51] }\end{array}$ & Self rating & $x$ & - \\
\hline social support & $\begin{array}{l}\text { Multidimensional Scale of } \\
\text { Perceived Social Support } \\
\text { (MSPSS) [52] }\end{array}$ & Self rating & $\mathrm{X}$ & - \\
\hline introspection & $\begin{array}{l}\text { Self-reflection and insight } \\
\text { scale (SRIS) }[53,54]\end{array}$ & Self rating & $\mathrm{X}$ & $\mathrm{x}$ \\
\hline self-efficacy & $\begin{array}{l}\text { Generalized Self-Efficacy } \\
\text { Scale (GSES) [55] }\end{array}$ & Self rating & $\mathrm{X}$ & - \\
\hline $\begin{array}{l}\text { psychosocial } \\
\text { functioning }\end{array}$ & $\begin{array}{l}\text { Global Functioning Social } \\
\text { and Role Scales (GF: Social } \\
\text { and Role) [56] }\end{array}$ & $\begin{array}{l}\text { Observer } \\
\text { rating }\end{array}$ & $X$ & - \\
\hline $\begin{array}{l}\text { Experience } \\
\text { with ESM } \\
\text { period }\end{array}$ & adapted from [57] & Self rating & - & $\mathrm{x}$ \\
\hline
\end{tabular}

Using ESM, potentially relevant transdiagnostic (subthreshold) symptoms such as sadness, anxiety, psychotic experiences und stress will be recorded (table 3). Items are based on previous studies and questionnaires, given the lack of standardized ESM assessment in clinical populations. In-app reminders will be sent out five times a day at fixed time points: 9:30h, 12:30h, 15:30h, 18:30h, 21:30h for a duration of 14 days. In each survey, participants will be asked how much they endorse a certain feeling or behavior at the time of filling out the survey: "How much does the following statement apply to you at this moment?". Responses will be given on a visual analogue scale (in percent) from " $0=$ does not apply at all" to " $100=$ applies fully", with a slider that can be moved in 1-unit increments. A visualization of the layout of the app (in German) is available from the corresponding author. Participants will be 
medRxiv preprint doi: https://doi.org/10.1101/2021.05.10.21256804; this version posted May 10, 2021. The copyright holder for this preprint (which was not certified by peer review) is the author/funder, who has granted medRxiv a license to display the preprint in perpetuity.

It is made available under a CC-BY 4.0 International license.

asked to fill in the items as soon as possible after receiving the in-app reminder, but no later than 60 minutes afterwards. Filling in the items takes about 1-1.5 minutes in total. Similar ESM protocols were deemed acceptable for clinical populations in prior studies $[28,57,58]$. The insightsapp will be used only for the regular active collection of transdiagnostic symptoms by means of the described self-report questions. No personal information (such as name, phone number, etc.) or passive data are accessed, stored or transferred by the insightsapp. To maximize the number of completed surveys for every participant, participants will be contacted at least once during the assessment period to assess instruction adherence, identify any concerns associated with the method and help participants with any problems in completing the ESM questionnaire.

Table 3. English translation of ESM items assessed in the PhenoNetz-study.

1. I am sad.

2. I perceive things that other people cannot perceive.

3. I have difficulties concentrating.

4. I feel sociable.

5. I feel stressed.

6. I am satisfied with myself.

7. I feel anxious.

8. I find it hard to motivate myself to do things.

9. I am suspicious of other people.

10. I am brooding. 
medRxiv preprint doi: https://doi.org/10.1101/2021.05.10.21256804; this version posted May 10, 2021. The copyright holder for this preprint (which was not certified by peer review) is the author/funder, who has granted medRxiv a license to display the preprint in perpetuity.

It is made available under a CC-BY 4.0 International license .

In the follow-up assessment conducted after the 14 days of ESM data collection, data on psychopathology, medication and substance use will be assessed again, referring to the 14 days during which ESM data were collected (table 2). In addition, experiences and strain associated with the ESM data collection will be assessed via a questionnaire translated and adjusted from a previous study conducted in clinical participants [57] (translated to German; available from the corresponding author). If desired, participants will be provided with a personalized feedback report on their ESM data.

\section{Data security}

Using a smartphone app installed on the personal smartphone of participants for data assessment requires particular attention to data security (for a broader discussion on ethical concerns regarding digital phenotyping procedures in the psychological and psychiatric sciences see $[59,60])$. Therefore, subjects must provide additional consent to collect data within the app and grant the necessary permissions to the app on the smartphones (such as being notified by the app about available surveys). The ESM data collected by the insightsapp is pseudonymized (16-digit alphanumeric codes) and sent directly to a server hosted and maintained by a professional web hosting service after each survey. Answers to the surveys are only stored temporarily locally on the smartphones and deleted once they are transmitted to the server. To secure the data transfer from the smartphone to the server, both the connection between the insightsapp and the backend software on the server is encrypted by the use of a SSL certificate.

\section{Safety}

Given that this study is observational, there are no direct risks associated with participation. Previous studies have demonstrated good acceptance of the ESM protocol implemented in this project. Even if participants become more aware of their symptoms due to high-frequency data collection, this does not have a negative effect in terms of worsening 
medRxiv preprint doi: https://doi.org/10.1101/2021.05.10.21256804; this version posted May 10, 2021. The copyright holder for this preprint (which was not certified by peer review) is the author/funder, who has granted medRxiv a license to display the preprint in perpetuity.

It is made available under a CC-BY 4.0 International license .

symptoms $[28,57,61]$. Participants can terminate the ESM data collection at any time without giving reasons. Participants who are acutely suicidal or a danger to others will immediately be presented to the service physician for further assessment. Should this become apparent in a telephone call, participants will be reported to the responsible social psychiatric service.

\section{Data analytic plan}

All statistical analyses will be conducted in the $R$ language for statistical computing [62]. Descriptive analysis of the sample will include mean, standard deviation, median and interquartile range as appropriate. Participants included in the analysis will be compared to those that dropped out of the study or were excluded due to too little available measurements $(<20$ measurements $[63,64])$ via appropriate classes of permutation tests [65]. Changes in measures that were assessed twice, pre- and post-ESM (see table 2), will be compared via linear mixed modeling. Prior to the analyses of ESM data, we will detrend the ESM data by fitting fixed-effects linear regression models to each ESM item, regressing out a linear trend on time (i.e., general increases/decreases in items over time). We will then generate both within-person group level and individual person networks as described in detail below. These analyses allow us to examine symptom dynamics both within one individual $(n=1)$, as well as averages within multiple individuals $(n>1)$.

\section{Individual networks}

For each participant, we will generate both temporal (a directed network displaying symptoms predicting each other across an approximately 3-h lag, while controlling for all other experiences in the model at the prior measurement) and contemporaneous networks (an undirected partial correlation network showing how the 10 assessed transdiagnostic symptoms relate to each other in the same window of measurement, controlling for the previous time point (temporal effects)). Both contemporaneous and temporal idiographic networks provide 
medRxiv preprint doi: https://doi.org/10.1101/2021.05.10.21256804; this version posted May 10, 2021. The copyright holder for this preprint (which was not certified by peer review) is the author/funder, who has granted medRxiv a license to display the preprint in perpetuity.

It is made available under a CC-BY 4.0 International license .

important information on potential dynamics between symptoms, emotions and experiences for each participant [34]. These dynamics are indicative of psychopathological mechanisms specific to the individual. Technically, we will z-standardize the data per ESM item, and then use a Graphical Vector Autoregressive (GVAR) model using full information maximum likelihood estimation (FIML) to account for missing data, and stepwise model search to find an optimal model that minimizes some the Bayesian Information Criterion (BIC), thresholding at $\alpha=.01$ for the pruning or addition of individual edges ( $R$ package 'psychonetrics' [66]). To assess the most central symptoms in the contemporaneous network, we will compute strength centrality, a commonly used index of centrality. For the temporal network (3h lag), In-Strength (how much input a symptom received from other symptoms) and Out-Strength (how much output a symptom provides to other symptoms) values will be calculated. The indices of centrality will be calculated using the $R$ package 'qgraph' [67].

\section{Group-level networks}

We will mean-center ESM items per person, and then use the multi-level vector autoregressive (mlVAR) $R$ package to estimate three group-level network structures including the 10 assessed symptoms, reflecting the average process of all participants: between-subject (undirected partial correlation network between the means of participant's scores, capturing, in general, whether participants high on a given node are also high on other nodes during the twoweek course of the study), contemporaneous (an undirected partial correlation network showing how symptoms relate to each other in the same window of measurement, controlling for temporal relationships), and temporal (a directed network displaying symptoms predicting each other across an approximately 3-h lag, while controlling for all other experiences in the model at the prior measurement). See $[34,63,64]$ for a detailed description of methodological 
medRxiv preprint doi: https://doi.org/10.1101/2021.05.10.21256804; this version posted May 10, 2021. The copyright holder for this preprint (which was not certified by peer review) is the author/funder, who has granted medRxiv a license to display the preprint in perpetuity.

It is made available under a CC-BY 4.0 International license .

details. Centrality will be assessed using strength centrality in the contemporaneous network, and In-Strength and Out-Strength in the temporal network ( $R$ package 'qgraph' [67]).

\section{Aims and hypothesis}

Our hypotheses will be tested in the following steps:

1. We will compute both group longitudinal (between-person, contemporaneous, temporal) networks and individual longitudinal networks (contemporaneous and temporal; see [34]) as described above. In line with prior clinical research [58], we hypothesize that networks will be highly variable across individuals and show relevant deviations of individual networks from group level networks, showcasing the importance of generating personalized models.

2. We will identify symptom centrality and unique partial correlations among symptoms in each network for each type of network as described above. We hypothesize that on group level, feeling stressed will be the most central symptom in the contemporaneous network and predict other experiences in the temporal network, given that stress experience is frequently discussed as a transdiagnostic factor in psychopathological experiences [22-25].

3. We will evaluate the degree of association between risk factors (e.g. childhood trauma) and network connectivity, assessed by global strength of individual networks (temporal and contemporaneous), in a linear modeling approach. Based on prior research and theoretical considerations [68-70], we hypothesize that risk factors will be associated with an increased network connectivity. Similarly, we hypothesize that poorer psychosocial functioning will be associated with increased network connectivity.

4. We will identify most variable partial correlations (i.e., associations between symptoms that vary the most across participants), most variable central symptoms (i.e. symptoms that vary the 
medRxiv preprint doi: https://doi.org/10.1101/2021.05.10.21256804; this version posted May 10, 2021. The copyright holder for this preprint (which was not certified by peer review) is the author/funder, who has granted medRxiv a license to display the preprint in perpetuity.

It is made available under a CC-BY 4.0 International license .

most across participants in their centrality in individual contemporaneous networks, as assessed with strength centrality), and most variable predictive symptoms in individual temporal networks (i.e. symptoms that vary the most across participants in their predictivity in individual temporal networks, as assessed with out-degree strength centrality) and associated them with risk/resilience factors as well as sociodemographic factors in an explorative fashion.

5. We hypothesize that after participation in the study, patients will demonstrate more selfreflection than at baseline, as indicated by significant increases in the self-reflection and insights-scale total score from baseline to follow-up (post-ESM assessment, assessed by linear modeling).

\section{Required number of ESM observations}

Due to the methodological novelty of individualized networks based on intensive time series data, there exist no guidelines on the number of ESM observations required [64]. More observations collected over a longer period of time improves stability and validity of the results; however, this has to be balanced against the feasibility of the integration of the study into the daily lives of the participants. Additionally, the performance of network estimation methods depends on the unknown true network structure - the network equivalent of a true effect size in power analysis [34,64]. In a simulation study [71], for a person-specific network consisting of 8 items, 50 observations were deemed sufficient, i.e. about 6.25 observations per item. In our study, we included 10 items, for which we ideally will obtain 70 observations each, which leaves room for 7 missed surveys (10\%) given a target of at least 63 observations. With fewer observations, estimated edges can still be interpreted to represent true edges, but one might miss on estimating other, smaller true edges [34,71].

\section{Sample size}


medRxiv preprint doi: https://doi.org/10.1101/2021.05.10.21256804; this version posted May 10, 2021. The copyright holder for this preprint (which was not certified by peer review) is the author/funder, who has granted medRxiv a license to display the preprint in perpetuity.

It is made available under a CC-BY 4.0 International license .

Formal power analyses are not yet worked out for group-level network models based on intensive longitudinal data. Supplementary materials from Epskamp, Waldorp, et al. (2018) report simulation results for mlVAR, showing that mlVAR models are excellent in recovering the fixed effect structures with quite few data, starting at 50 observations. With our targeted sample size of 75 , we will surpass this threshold.

\section{Status and timeline of the study}

Study recruitment started on November 11, 2020, and is currently ongoing, with an anticipated date of recruitment completion of November 2021.

\section{Discussion}

This study aims at an explorative phenotyping of the heterogenous help-seeking population of a psychiatric early recognition center. Applying ESM, we will identify transdiagnostic symptom networks and their association with protective and risk factors, as well as psychosocial functioning. In doing so, we provide a first attempt to validly depict symptoms of the proposed broad transdiagnostic risk syndrome. An explorative phenotyping of the proposed transdiagnostic risk syndrome, combining ESM and network analysis, might provide valuable insights on group- as well as on individual level: Central items and processes might represent anchor points for interventions. Furthermore, insights into potential etiological processes, identified by association with risk factors and resilience factors, might inform prevention strategies. Similarly, etiological processes connected to psychosocial functioning might inform effective interventions for psychosocial disabilities, which are still lacking [35]. Hypotheses about the proposed broad transdiagnostic risk syndrome or effective interventions based on findings of our explorative study might guide future research. Likewise, potential impact of self-monitoring by the high-frequent assessment of ESM needs to be followed by impact studies, testing if ESM could serve as an intervention in help- 
medRxiv preprint doi: https://doi.org/10.1101/2021.05.10.21256804; this version posted May 10, 2021. The copyright holder for this preprint (which was not certified by peer review) is the author/funder, who has granted medRxiv a license to display the preprint in perpetuity.

It is made available under a CC-BY 4.0 International license.

seeking populations. Moreover, ESM only represents one powerful element to gain insights into relevant variables collected in everyday life to improve prevention and targeted early intervention [72,73]. Studying the digital footprints left by the human-smartphone interaction (e.g. log in frequency, use of different apps, calling behavior), can provide additional important insights into psychopathological states in help-seeking individuals [74].

Work in this area is deservedly receiving more and more attention [27,32,64], and we believe that this will result in enhanced patient benefit. Our study intends to contribute a milestone towards innovation of personalized early recognition in psychiatry, allowing to help a greater proportion of heterogeneous help-seeking populations [32]. Subsequent impacts on early states and the progress of mental disorders might reduce associated personal, familial, societal, clinical as well as economic burden more effectively.

\section{References}

1. Marshall M, Husain N, Bork N, Chaudhry IB, Lester H, Everard L, et al. Impact of early intervention services on duration of untreated psychosis: data from the National EDEN prospective cohort study. Schizophr Res. 2014;159: 1-6. doi:10.1016/j.schres.2014.07.005

2. Valmaggia LR, Byrne M, Day F, Broome MR, Johns L, Howes O, et al. Duration of untreated psychosis and need for admission in patients who engage with mental health services in the prodromal phase. Br J Psychiatry. 2015;207: 130-134. doi:10.1192/bjp.bp.114.150623

3. Fusar-Poli P, Bauer M, Borgwardt S, Bechdolf A, Correll CU, Do KQ, et al. European college of neuropsychopharmacology network on the prevention of mental disorders and mental health promotion (ECNP PMD-MHP). Eur Neuropsychopharmacol. 2019;29: 1301-1311. doi:10.1016/j.euroneuro.2019.09.006

4. Schultze-Lutter F, Michel C, Schmidt SJ, Schimmelmann BG, Maric NP, Salokangas RKR, et al. EPA guidance on the early detection of clinical high risk states of psychoses. Eur Psychiatry. 2015;30: 405-416. doi:10.1016/j.eurpsy.2015.01.010

5. Rosen M, Betz LT, Schultze-Lutter F, Chisholm K, Haidl TK, Kambeitz-Ilankovic L, et al. Towards clinical application of prediction models for transition to psychosis: A systematic review and external validation study in the PRONIA sample. Neurosci Biobehav Rev. 2021;125: 478-492. doi:10.1016/j.neubiorev.2021.02.032

6. Schultze-Lutter F, Ruhrmann S, Klosterkötter J. Early detection of psychosis - establishing a service for persons at risk. Eur Psychiatry. 2009;24: 1-10. doi:10.1016/j.eurpsy.2008.08.004

7. Iorfino F, Scott EM, Carpenter JS, Cross SP, Hermens DF, Killedar M, et al. Clinical Stage Transitions in Persons Aged 12 to 25 Years Presenting to Early Intervention Mental Health 
medRxiv preprint doi: https://doi.org/10.1101/2021.05.10.21256804; this version posted May 10, 2021. The copyright holder for this preprint (which was not certified by peer review) is the author/funder, who has granted medRxiv a license to display the preprint in perpetuity.

It is made available under a CC-BY 4.0 International license .

Services With Anxiety, Mood, and Psychotic Disorders. JAMA Psychiatry. 2019;76: 1167-1175. doi:10.1001/jamapsychiatry.2019.2360

8. Rickwood DJ, Telford NR, Parker AG, Tanti CJ, McGorry PD. headspace - Australia's innovation in youth mental health: who are the clients and why are they presenting? Med J Aust. 2014;200: 108-111. doi:10.5694/mja13.11235

9. Wittchen HU, Jacobi F, Rehm J, Gustavsson A, Svensson M, Jönsson B, et al. The size and burden of mental disorders and other disorders of the brain in Europe 2010. Eur Neuropsychopharmacol. 2011;21: 655-679. doi:10.1016/j.euroneuro.2011.07.018

10. McElroy E, Fearon P, Belsky J, Fonagy P, Patalay P. Networks of Depression and Anxiety Symptoms Across Development. J Am Acad Child Adolesc Psychiatry. 2018;57: 964-973. doi:10.1016/j.jaac.2018.05.027

11. Rozin P, Royzman EB. Negativity Bias, Negativity Dominance, and Contagion. Pers Soc Psychol Rev. 2001;5: 296-320. doi:10.1207/S15327957PSPR0504_2

12. van Os J, Linscott RJ, Myin-Germeys I, Delespaul P, Krabbendam L. A systematic review and meta-analysis of the psychosis continuum: evidence for a psychosis proneness-persistenceimpairment model of psychotic disorder. Psychol Med. 2009;39: 179-195. doi:10.1017/S0033291708003814

13. Wigman JTW, van Nierop M, Vollebergh WAM, Lieb R, Beesdo-Baum K, Wittchen H-U, et al. Evidence that psychotic symptoms are prevalent in disorders of anxiety and depression, impacting on illness onset, risk, and severity--implications for diagnosis and ultra-high risk research. Schizophr Bull. 2012;38: 247-257. doi:10.1093/schbul/sbr196

14. Hartmann JA, Nelson B, Spooner R, Paul Amminger G, Chanen A, Davey CG, et al. Broad clinical high-risk mental state (CHARMS): Methodology of a cohort study validating criteria for pluripotent risk. Early Interv Psychiatry. 2019;13: 379-386. doi:10.1111/eip.12483

15. van Os J, Guloksuz S. A critique of the "ultra-high risk" and "transition" paradigm. World Psychiatry. 2017;16: 200-206. doi:10.1002/wps.20423

16. Addington J, Stowkowy J, Liu L, Cadenhead KS, Cannon TD, Cornblatt BA, et al. Clinical and functional characteristics of youth at clinical high-risk for psychosis who do not transition to psychosis. Psychol Med. 2019;49: 1670-1677. doi:10.1017/S0033291718002258

17. Gibson LE, Alloy LB, Ellman LM. Trauma and the psychosis spectrum: A review of symptom specificity and explanatory mechanisms. Clin Psychol Rev. 2016;49: 92-105.

doi:10.1016/j.cpr.2016.08.003

18. Nusslock R, Alloy LB. Reward processing and mood-related symptoms: An RDoC and translational neuroscience perspective. J Affect Disord. 2017;216: 3-16.

doi:10.1016/j.jad.2017.02.001

19. Cicchetti D, Rogosch FA. Equifinality and multifinality in developmental psychopathology. Dev Psychopathol. 1996;8: 597-600. doi:10.1017/S0954579400007318

20. Hartmann JA, McGorry PD, Destree L, Amminger GP, Chanen AM, Davey CG, et al. Pluripotential Risk and Clinical Staging: Theoretical Considerations and Preliminary Data From a Transdiagnostic Risk Identification Approach. Front Psychiatry. 2020;11: 553578. doi:10.3389/fpsyt.2020.553578

21. Monroe SM. Modern approaches to conceptualizing and measuring human life stress. Annu Rev 
medRxiv preprint doi: https://doi.org/10.1101/2021.05.10.21256804; this version posted May 10, 2021. The copyright holder for this preprint (which was not certified by peer review) is the author/funder, who has granted medRxiv a license to display the preprint in perpetuity.

It is made available under a CC-BY 4.0 International license .

Clin Psychol. 2008;4: 33-52. doi:10.1146/annurev.clinpsy.4.022007.141207

22. Calcia MA, Bonsall DR, Bloomfield PS, Selvaraj S, Barichello T, Howes OD. Stress and neuroinflammation: a systematic review of the effects of stress on microglia and the implications for mental illness. Psychopharmacology. 2016;233: 1637-1650. doi:10.1007/s00213-016-4218-9

23. Betz LT, Penzel N, Rosen M, Kambeitz J. Relationships between childhood trauma and perceived stress in the general population: a network perspective. Psychol Med. 2020; 1-11. doi:10.1017/S003329172000135X

24. Myin-Germeys I, van Os J. Stress-reactivity in psychosis: evidence for an affective pathway to psychosis. Clin Psychol Rev. 2007;27: 409-424. doi:10.1016/j.cpr.2006.09.005

25. Isvoranu A-M, van Borkulo CD, Boyette L-L, Wigman JTW, Vinkers CH, Borsboom D, et al. A Network Approach to Psychosis: Pathways Between Childhood Trauma and Psychotic Symptoms. Schizophr Bull. 2017;43: 187-196. doi:10.1093/schbul/sbw055

26. Borsboom D, Cramer AOJ. Network analysis: an integrative approach to the structure of psychopathology. Annu Rev Clin Psychol. 2013;9: 91-121. doi:10.1146/annurev-clinpsy050212-185608

27. Hofmann SG, Curtiss J, McNally RJ. A Complex Network Perspective on Clinical Science. Perspect Psychol Sci. 2016;11: 597-605. doi:10.1177/1745691616639283

28. Verhagen SJW, Hasmi L, Drukker M, van Os J, Delespaul PAEG. Use of the experience sampling method in the context of clinical trials. Evid Based Ment Health. 2016;19: 86-89. doi:10.1136/ebmental-2016-102418

29. Miller G. The Smartphone Psychology Manifesto. Perspect Psychol Sci. 2012;7: 221-237. doi:10.1177/1745691612441215

30. Markowetz A, Błaszkiewicz K, Montag C, Switala C, Schlaepfer TE. Psycho-informatics: Big Data shaping modern psychometrics. Med Hypotheses. 2014;82: 405-411. doi:10.1016/j.mehy.2013.11.030

31. Fisher AJ, Boswell JF. Enhancing the Personalization of Psychotherapy With Dynamic Assessment and Modeling. Assessment. 2016;23: 496-506. doi:10.1177/1073191116638735

32. Hofmann SG, Hayes SC. The Future of Intervention Science: Process-Based Therapy. Clin Psychol Sci. 2019;7: 37-50. doi:10.1177/2167702618772296

33. van Os J, Guloksuz S, Vijn TW, Hafkenscheid A, Delespaul P. The evidence-based group-level symptom-reduction model as the organizing principle for mental health care: time for change? World Psychiatry. 2019;18: 88-96. doi:10.1002/wps.20609

34. Epskamp S, van Borkulo CD, van der Veen DC, Servaas MN, Isvoranu A-M, Riese H, et al. Personalized Network Modeling in Psychopathology: The Importance of Contemporaneous and Temporal Connections. Clin Psychol Sci. 2018;6: 416-427. doi:10.1177/2167702617744325

35. Mei C, van der Gaag M, Nelson B, Smit F, Yuen HP, Berger M, et al. Preventive interventions for individuals at ultra high risk for psychosis: An updated and extended meta-analysis. Clin Psychol Rev. 2021; 102005. doi:10.1016/j.cpr.2021.102005

36. Harris PA, Taylor R, Thielke R, Payne J, Gonzalez N, Conde JG. Research electronic data capture (REDCap)--a metadata-driven methodology and workflow process for providing translational research informatics support. J Biomed Inform. 2009;42: 377-381.

doi:10.1016/j.jbi.2008.08.010 
medRxiv preprint doi: https://doi.org/10.1101/2021.05.10.21256804; this version posted May 10, 2021. The copyright holder for this preprint (which was not certified by peer review) is the author/funder, who has granted medRxiv a license to display the preprint in perpetuity.

It is made available under a CC-BY 4.0 International license .

37. Montag C, Baumeister H, Kannen C, Sariyska R, Meßner E-M, Brand M. Concept, Possibilities and Pilot-Testing of a New Smartphone Application for the Social and Life Sciences to Study Human Behavior Including Validation Data from Personality Psychology. J - Multidisciplinary Scientific Journal. 2019;2: 102-115. doi:10.3390/j2020008

38. Sheehan DV, Lecrubier Y, Sheehan KH, Amorim P, Janavs J, Weiller E, et al. The MiniInternational Neuropsychiatric Interview (M.I.N.I.): the development and validation of a structured diagnostic psychiatric interview for DSM-IV and ICD-10. J Clin Psychiatry. 1998;59 Suppl 20: 22-33;quiz 34-57. Available: https://www.ncbi.nlm.nih.gov/pubmed/9881538

39. Koutsouleris N, Kambeitz-Ilankovic L, Ruhrmann S, Rosen M, Ruef A, Dwyer DB, et al. Prediction Models of Functional Outcomes for Individuals in the Clinical High-Risk State for Psychosis or With Recent-Onset Depression: A Multimodal, Multisite Machine Learning Analysis. JAMA Psychiatry. 2018;75: 1156-1172. doi:10.1001/jamapsychiatry.2018.2165

40. Strunk KK, Lane FC. The Beck Depression Inventory, Second Edition (BDI-II): A Cross-Sample Structural Analysis. Measurement and Evaluation in Counseling and Development. 2016.

41. Spielberg CD, Gorsuch RL, Lushene RD. Test Manual for the State-Trait Anxiety Inventory. Consulting psychologists press Palo Alto, California; 1970.

42. Sosic Z, Gieler U, Stangier U. Screening for social phobia in medical in- and outpatients with the German version of the Social Phobia Inventory (SPIN). J Anxiety Disord. 2008;22: 849-859. doi:10.1016/j.janxdis.2007.08.011

43. Schlier B, Jaya ES, Moritz S, Lincoln TM. The Community Assessment of Psychic Experiences measures nine clusters of psychosis-like experiences: A validation of the German version of the CAPE. Schizophr Res. 2015;169: 274-279. doi:10.1016/j.schres.2015.10.034

44. Angermeyer C, Kilian R, Matschinger H. WHOQoL-100 und WHOQoL-BREF. Handbuch für die deutschsprachigen Versionen der WHO Instrumente zur Erfassung von Lebensqualität. Hogrefe; 2000.

45. Wingenfeld K, Spitzer C, Mensebach C, Grabe HJ, Hill A, Gast U, et al. [The German Version of the Childhood Trauma Questionnaire (CTQ):Preliminary Psychometric Properties.]. Psychother Psychosom Med Psychol. 2010;60: e13. doi:10.1055/s-0030-1253494

46. Haidl TK, Schneider N, Dickmann K, Ruhrmann S, Kaiser N, Rosen M, et al. Validation of the Bullying Scale for Adults - Results of the PRONIA-study. J Psychiatr Res. 2020;129: 88-97. doi:10.1016/j.jpsychires.2020.04.004

47. Kaiser N, Seves M, Koutsouleris N, Ruhrmann S. Validierung einer deutschen Version der Resilience Scale for Adults (RSA). Diagnostica. 2019;65: 205-215. doi:10.1026/00121924/a000228

48. Kälin W. Deutsche 24-Item Kurzform des „Coping Inventory for Stressful Situations(CISS)“ von N. S. Endler \& J. D. A. Parker. Basierend auf der Übersetzung von N. Semmer, F.Tschan \& V. Schade (unveröffentlichter Fragebogen). Bern: Universität, Institut für Psychologie.; 1995.

49. Scandell DJ. Development and initial validation of validity scales for the NEO-Five Factor Inventory. Pers Individ Dif. 2000;29: 1153-1162. doi:10.1016/S0191-8869(99)00262-7

50. Hexel M. Validierung der deutschen Version des Attachment Style Questionnaire (ASQ) bei Personen mit und ohne psychiatrische Diagnosen. Zeitschrift für Klinische Psychologie und Psychotherapie. 2004;33: 79-90. doi:10.1026/0084-5345.33.2.79 
medRxiv preprint doi: https://doi.org/10.1101/2021.05.10.21256804; this version posted May 10, 2021. The copyright holder for this preprint (which was not certified by peer review) is the author/funder, who has granted medRxiv a license to display the preprint in perpetuity.

It is made available under a CC-BY 4.0 International license .

51. Gerlsma C, Hale WW 3rd. Predictive power and construct validity of the Level of Expressed Emotion (LEE) scale. Depressed out-patients and couples from the general community. $\mathrm{Br} \mathbf{J}$ Psychiatry. 1997;170: 520-525. doi:10.1192/bjp.170.6.520

52. Zimet GD, Dahlem NW, Zimet SG, Farley GK. The Multidimensional Scale of Perceived Social Support. J Pers Assess. 1988;52: 30-41. doi:10.1207/s15327752jpa5201_2

53. Grant AM, Franklin J, Langford P. The Self-Reflection and Insight Scale: A New Measure of Private Self-Consciousness. Social Behavior and Personality An International Journal. 2002;30: 821-835. doi:10.2224/sbp.2002.30.8.821

54. Zygar C, Hagemeyer B, Pusch S, Schönbrodt FD. From motive dispositions to states to outcomes: An intensive experience sampling study on communal motivational dynamics in couples: From motive dispositions to states to outcomes. Eur J Pers. 2018;32: 306-324. doi:10.1002/per.2145

55. Schwarzer R. Skala zur Allgemeinen Selbstwirksamkeitserwartung. 1999.

56. Cornblatt BA, Auther AM, Niendam T, Smith CW, Zinberg J, Bearden CE, et al. Preliminary findings for two new measures of social and role functioning in the prodromal phase of schizophrenia. Schizophr Bull. 2007;33: 688-702. doi:10.1093/schbul/sbm029

57. Frumkin M, Piccirillo M, Beck ED, Grossman J, Rodebaugh T. Feasibility and utility of idiographic models in the clinic: A pilot study. Psychother Res. 2020.

doi:10.1080/10503307.2020.1805133

58. Levinson CA, Vanzhula I, Brosof LC. Longitudinal and personalized networks of eating disorder cognitions and behaviors: Targets for precision intervention a proof of concept study. Int J Eat Disord. 2018;51: 1233-1243. doi:10.1002/eat.22952

59. Montag C, Sindermann C, Baumeister H. Digital phenotyping in psychological and medical sciences: a reflection about necessary prerequisites to reduce harm and increase benefits. Curr Opin Psychol. 2020;36: 19-24. doi:10.1016/j.copsyc.2020.03.013

60. Dagum P, Montag C. Ethical Considerations of Digital Phenotyping from the Perspective of a Healthcare Practitioner. In: Baumeister H, Montag C, editors. Digital Phenotyping and Mobile Sensing: New Developments in Psychoinformatics. Cham: Springer International Publishing; 2019. pp. 13-28. doi:10.1007/978-3-030-31620-4_2

61. van Genugten CR, Schuurmans J, Lamers F, Riese H, Penninx BW, Schoevers RA, et al. Experienced Burden of and Adherence to Smartphone-Based Ecological Momentary Assessment in Persons with Affective Disorders. J Clin Med Res. 2020;9. doi:10.3390/jcm9020322

62. R Core Team. R: A Language and Environment for Statistical Computing. Vienna, Austria: R Foundation for Statistical Computing; 2020. Available: https://www.R-project.org/

63. Epskamp S, Waldorp LJ, Mõttus R, Borsboom D. The Gaussian Graphical Model in CrossSectional and Time-Series Data. Multivariate Behav Res. 2018;53: 453-480. doi:10.1080/00273171.2018.1454823

64. Jordan DG, Winer ES, Salem T. The current status of temporal network analysis for clinical science: Considerations as the paradigm shifts? J Clin Psychol. 2020;76: 1591-1612. doi:10.1002/jclp.22957 